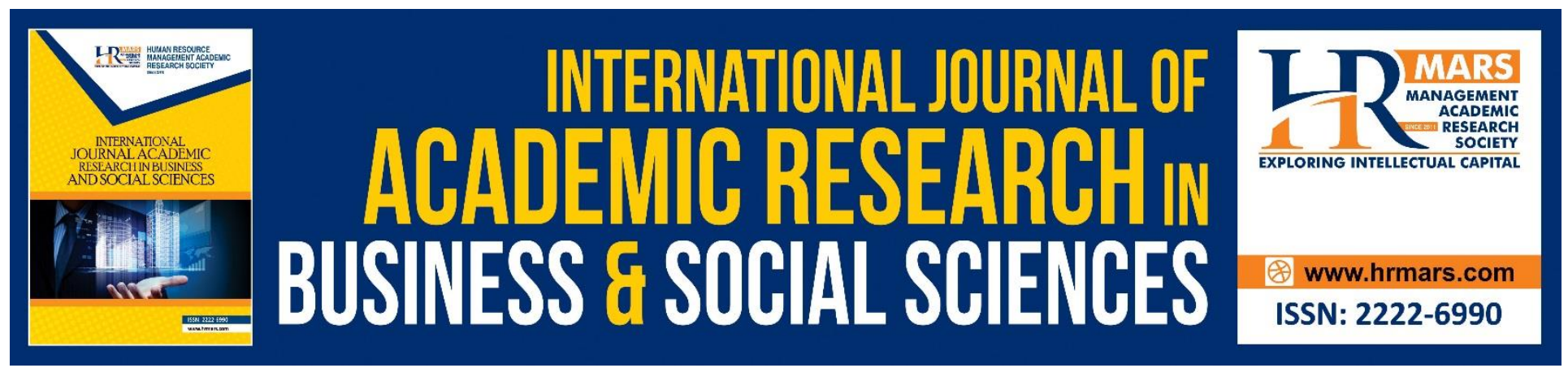

\title{
Computational Thinking (Algorithms) Through Unplugged Programming Activities: Exploring Upper Primary Students' Learning Experiences
}

Bih Loong Lim, Chwen Jen Chen

To Link this Article: http://dx.doi.org/10.6007/IJARBSS/v11-i14/8946

DOI:10.6007/IJARBSS/v11-i14/8946

Received: 20 January 2021, Revised: 22 February 2021, Accepted: 19 March 2021

Published Online: 31 March 2021

In-Text Citation: (Lim \& Chen, 2021)

To Cite this Article: Lim, B. L., \& Chen, C. J. (2021). Computational Thinking (Algorithms) Through Unplugged Programming Activities: Exploring Upper Primary Students' Learning Experiences. International Journal of Academic Research in Business and Social Sciences, 11(14), 384-403.

Copyright: (C) 2021 The Author(s)

Published by Human Resource Management Academic Research Society (www.hrmars.com)

This article is published under the Creative Commons Attribution (CC BY 4.0) license. Anyone may reproduce, distribute, translate and create derivative works of this article (for both commercial and non-commercial purposes), subject to full attribution to the original publication and authors. The full terms of this license may be seen

at: http://creativecommons.org/licences/by/4.0/legalcode

Special Issue: Contemporary Business and Humanities Landscape Towards Sustainability, 2021, Pg. 384 - 403 http://hrmars.com/index.php/pages/detail/IJARBSS JOURNAL HOMEPAGE

Full Terms \& Conditions of access and use can be found at http://hrmars.com/index.php/pages/detail/publication-ethics 


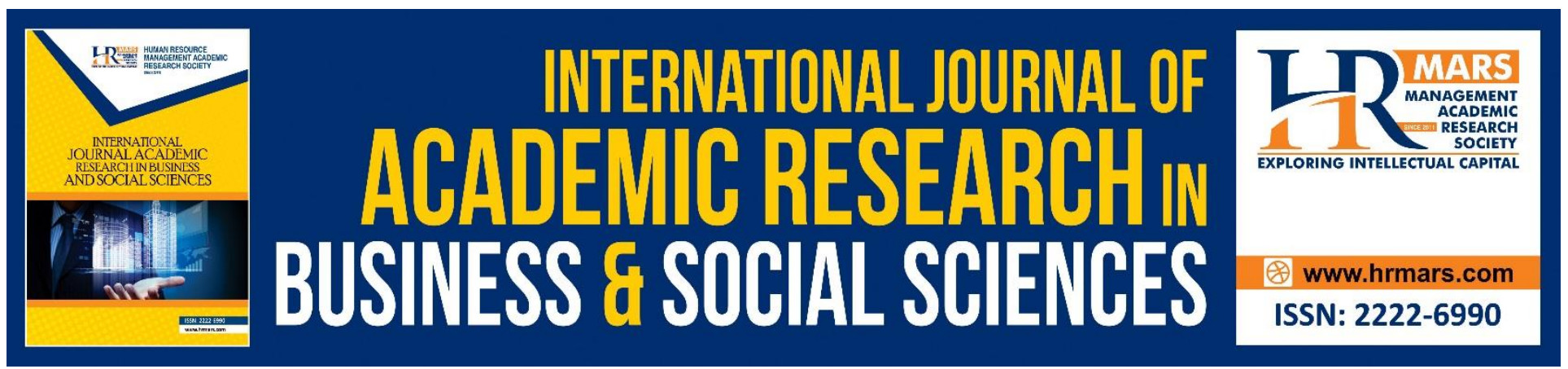

\title{
Computational Thinking (Algorithms) Through Unplugged Programming Activities: Exploring Upper Primary Students' Learning Experiences
}

\author{
Bih Loong Lim, Chwen Jen Chen \\ Faculty of Cognitive Sciences and Human Development, Universiti Malaysia Sarawak, 94300 Kota \\ Samarahan, Sarawak, Malaysia \\ Email: cjchen@unimas.my
}

\begin{abstract}
In the recent year, Computational Thinking (CT) has gained much attention in educational research and practice. CT skills can be taught via computing activities that involve different types of programming tasks or via Unplugged Programming Activities (UPA) that do not involve the use of digital devices to represent and deliver programming concepts. UPA is an appropriate teaching approach for schools that do not have sufficient technological infrastructure. Studies have shown the effectiveness of UPA in developing CT skills and is comparable to the technology driven learning method. The aim of this study is to explore the experience of primary school students on their learning of algorithms, which is one of the CT skills, through the UPA method. A total of 31 students from a rural primary school were exposed to the learning about the algorithm concept (an aspect of CT skills) via UPA learning materials. From the responses gathered through interviewing nine of these participants, four main themes (Good Learning Quality, Much Knowledge, Easy and Useful) related to their learning experiences have been derived. These positive themes provide evidence on the appropriateness of employing UPA for teaching the algorithm aspect of $\mathrm{CT}$, particularly for schools located in areas with limited access to adequate technological infrastructure. This study may serve as a reference in establishing a comprehensive UPA module for teaching algorithms aspect of CT skills.
\end{abstract}

Keywords: Computational Thinking, Unplugged Programming Activities, Algorithms

\section{Introduction}

The term Computational Thinking (CT) was first introduced in 2006 (Selby, 2013). CT skills refer to a collection of mental tools that enables an individual to solve problems more effectively by imitating a computer scientist's way of thinking (Wing, 2006). It is an approach for solving problems, designing systems and comprehending human behaviour that draws on the fundamental concepts of programming (Wing, 2006). Over the past decade, CT has gained much attention in educational research and practice (Wright, Rich, \& Leatham, 2012; Shute, Sun \& Asbell-Clarke, 2017). Many 
researchers view CT skills as essential in computer coding or programming (Wing, 2010; Wright et al., 2012; Shute et al., 2017). However, according to National Research Council (2012), CT skills are relevant not only to programmers but should also be acquired by everyone.

Today, CT is considered as one of the skills that must be taught, learnt and mastered by the young generation (Weintrop et al., 2014). Mastering CT skills will provide this young generation with greater opportunities to build up their competitiveness in the fast-paced digital economy (Bocconi et al., 2016; Weintrop et al., 2014). CT skills have been integrated into the education systems across the world and Malaysia is the first country in South East Asia region that incorporates CT skills into its national curriculum (Abas, 2016).

CT skills are often taught via computing activities that involve different types of programming tasks (Brackmann, et. al., 2017). However, another approach to teach CT skills is via Unplugged Programming Activities (UPA). UPA is defined as activities that do not involve the use of digital devices; instead-logic games, cards, strings or physical movements are used to develop the understanding on programming concepts (Kalelioglu, Gülbahar \& Kukul, 2016). UPA is an appropriate teaching approach for schools that do not have sufficient technological infrastructure such as electricity, Internet, computers, mobile devices, and/or other electronic devices (Amrita, Muir \& Rao, 2016).

The limited access to technological devices and facilities such as computers, tablets, educational robotics and other devices is a global issue (Sadatul, 2017). Countries in Africa, Asia and even many parts of European continent are still left behind with regards to the implementation of technology-based teaching and learning approach (UNESCO Institute for Statistics, 2014). A similar situation is found in Malaysia where the use of technology in education, particularly in some rural areas, is still in its infancy. Fifty percent (50\%) of teachers use their own computers for teaching and learning purposes in five areas of Selangor and $35 \%$ of schools do not have well-equipped computer laboratories and servers (Samuel \& Zaiton, 2007) while in a recent report, about $70 \%$ of schools in Sarawak recorded minimal use of information and communication technology (ICT) for teaching and learning and about $6 \%$, mostly in the rural and interior, still require much assistance and intervention for its adoption (Aubrey, 2019). Hence, UPA can be a great alternative to teach CT skills in such schools. The aim of this study is to explore the experience of primary school students on their learning of algorithms, which is one of the CT skills, through the UPA method.

\section{Computational Thinking (CT) Skills}

Six Distinctive Aspects of CT Skills

Computational thinking is one of the crucial skills for successful problem solving in an innovation driven and complex society (Kale et al., 2018). According to Shute et al. (2017), CT skills consists of six aspects;
(a) Abstraction - identify the important elements of a problem or situation
(b) Decomposition - breaking a problem into smaller parts.
(c) Algorithms - identifying steps in solving a problem.
(d) Evaluation - finding the most efficient solution to a problem.
(e) Generalization or pattern recognition - applying a previous solution or approach to solve a problem.
(f) Automation - using the information-processing agent as the solution to a problem. 


\section{Effects of CT Skills on Learning}

The goal of learning CT is to improve knowledge on some fundamental elements of Computer Science and support problem solving based on computational concepts (Wing, 2006). The integration of CT skills in teaching and learning has brought positive impacts to students' academic achievement as well as their learning motivation (Mironova, Amitan \& Vilipõld, 2012; Weintrop et al., 2014; Gardeli \& Vosinakis, 2017). Mironova et al. (2012) reported that students, especially those from the weak group, showed improvement in their examination results for several subjects after learning CT skills. Their performance, particularly in Science and Mathematics subjects, has improved and thus, reducing the gap between them and the advanced group. Possessing CT skills also helps a learner to deepen the learning of certain contents, particularly for STEM subjects (Repenning, Webb, \& loannidou, 2010). Zaman et al. (2019) has also reported how group interaction benefits the development of computational thinking skill among rural children and Belanger, Christenson and Lopac (2018) examined the effects of teaching CT on the confidence and problem solving ability among students of different age levels in suburban and rural schools.

\section{Developing CT Skills Through UPA}

Brackmann et al. (2017) reported a significant increase in CT skills among students after being exposed to UPA in their teaching and learning sessions. The use of UPA in developing CT skills is as effective as using technology-driven systems or gadgets, thus turning it into a good alternative for introducing programming to students (Brackmann et al., 2017; Faber, Wierdsma, Doornbos, Van Der Ven, \& De Vette, 2017). The use of UPA in developing CT skills has also shown positive effects on students' motivation (Faber et al., 2017; Gardeli \& Vosinakis, 2017).

\section{Algorithm}

Algorithm is one the distinctive aspects of CT (Shute et al., 2017; Wing, 2006). Erickson (2019) defines algorithm as "an explicit, precise, unambiguous, mechanically-executable sequence of elementary instructions, usually intended to accomplish a specific purpose". Various problems can be solved using algorithms (Sharma \& Khurana, 2013). For example: How to plan a tour that involves visiting several towns in the cheapest possible order? How to share information as well as keep secrets? Algorithms are useful for solving routine questions or exercises in which algorithms can be derived based on previous experience (Bodner, 1987).

Increasing scholarly attention has been given to the importance of algorithms in our daily contexts (Musiani, 2013). Algorithms are seen as powerful entities to control, govern and shape numerous contexts moving beyond its conventional definition as encoded procedures to transform input data to a desired output (Lee, 2018; Musiani, 2013). As algorithms have been introduced to Malaysia education syllabus through the subject "Teknologi Maklumat dan Komunikasi (TMK) Information Technology and Communcation", it raises the question on how primary school students perceive the learning of the algorithm concept? Studies about algorithms as well as other CT skills have been carried out in many western countries, particularly in European countries. However, such studies are rather minimal in the Asia region. In Malaysia, studies on CT skills mostly focus on activities that involve the use of technological devices (Anna et al., 2017; Anna \& Sabariah, 2014). 


\section{Methodology}

\section{Research Design}

The study employed a mixed method where both quantitative and qualitative methods were used to gather data for the purpose of this study. A pre-test and post-test experimental design was used to assess 31 students' perceived learning of the algorithm skill of CT. Nine out of 31 participants were interviewed after exposing them to the concept of algorithm via the UPA approach.

\section{Learning Material}

The learning material which was designed to develop the concept of algorithms consisted of two parts. The first part is the grid for 'Steps for Making Fruit Salad' which was adapted from Computer Science Without a Computer (n.d.). In this part, as shown in Figure 1, students were required to draw arrows on the grid to indicate the steps. Students' performance on accomplishing the task will depict their ability to make planning of steps in solving a problem.

The second part requires students to list out all the steps for making fruit salad. This part, as shown in Figure 2, was adapted from "Teknologi Maklumat dan Komunikasi" Year 6 textbook for Malaysian primary education as well as the study by Brackmann et al. (2017). Students' performance on this task will depict their ability to give step-by-step instruction in solving a problem.

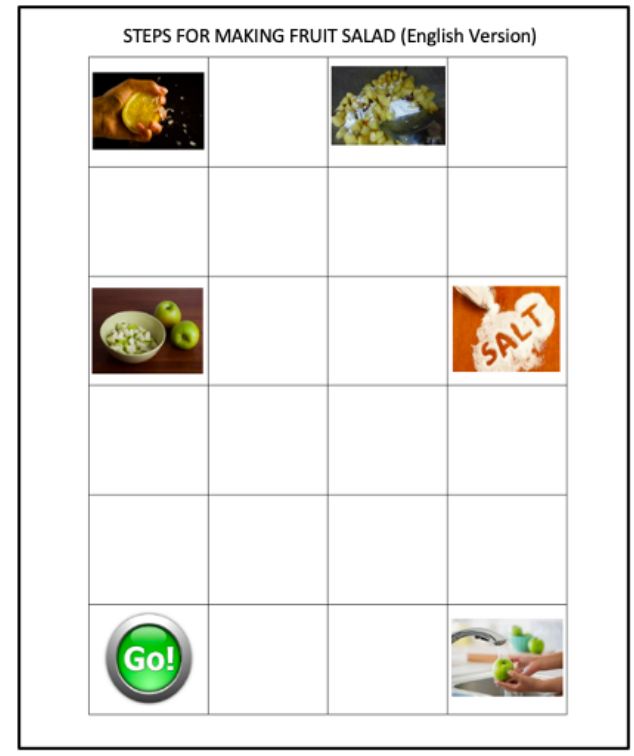

Figure 1 First Part - Grid for 'Steps for Making Fruit Salad' (Planning of steps) 


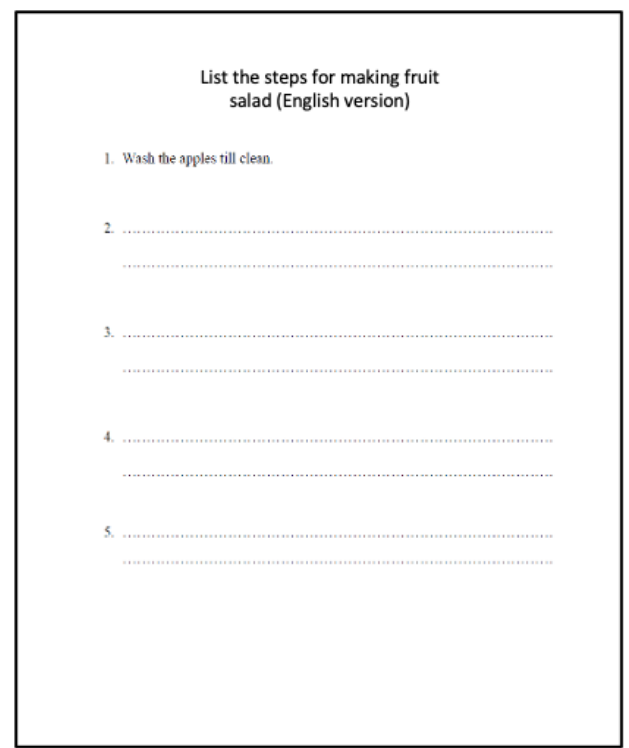

Figure 2 Second Part - List the Steps for Making Fruit Salad (Giving step-by-step instruction)

\section{Instruments}

Two instruments were developed for the purpose of this study:

- Students took the pre-test before experiencing the learning material and took the post-test after going through the learning material. The test consisted of two section: Section $A$ and Section B. Section A comprised five multiple-choice questions while Section B comprised three structured questions. The test was adapted from the Year 6 "Teknologi Maklumat dan Komunikasi (TMK)" textbook.

- Structured interview questions adapted from Chen and Keong (2017) were used to further explore students' perceived learning. Students with the highest scores and who showed more than 20 marks increment in their post-test scores compared with their pre-test scores were selected for the interview sessions.

\section{Participants}

Thirty-one students from one primary public school in Simunjan, Sarawak took part in this study. All participants were students of upper primary classes with their age ranging from 10 to 12 years old. From the thirty-one students who took part in pre-test and post-test, nine were chosen for the structured interview.

The selection of the participants for interview sessions were based on their performance in the pre-test and post-test. Four participants (P2, P5, P8, P9) scored 100\% mark in their post-test. Three participants (P3, P4, P6) showed increment of more than $20 \%$ in their post-test compared to their pre-test. Two participants (P1, P7) showed decrement of more than $15 \%$ in their post-test compared to their pre-test. Thus, the sample comprised students with perfect score, students who showed improvement in algorithm learning as well as students who showed deterioration in algorithm learning. 


\section{Data Collection Procedure}

The data collection was conducted after obtaining approval from the Ministry of Education, State Education Department and principal of the school involved in this study. The researcher briefed all 31 students and their parents on the purpose of the study. They were also informed about the audiotaping during the interview sessions. Parents of all participants had given their consent by signing the consent form witnessed by the school principal. All interview sessions were conducted after school and Malay language was used during the sessions as most students are better versed in this language.

The pre-test was administered to all the 31 students. They were exposed to the learning materials for about 40 minutes after school hours in batches. The post-test was administered right after each batch completed the learning materials.

\section{Data Analysis}

Data gathered from the pre-test and post-test were analysed using SPSS software. Paired ttest was carried out to examine whether there is a significance difference between the pre-test and post-test.

The interview data gathered was qualitatively analysed to identify the emerging themes. The interview transcript was read through and participants' significant responses toward the interview questions on perceived learning were coded. The appropriate themes were then derived from the compiled coded responses. Themes were classified into favourable and unfavourable responses. Through prompts and follow-up questions, descriptions and justifications of participants' favourable and unfavourable responses were gathered. Figure 3 shows the steps taken to derive the themes.

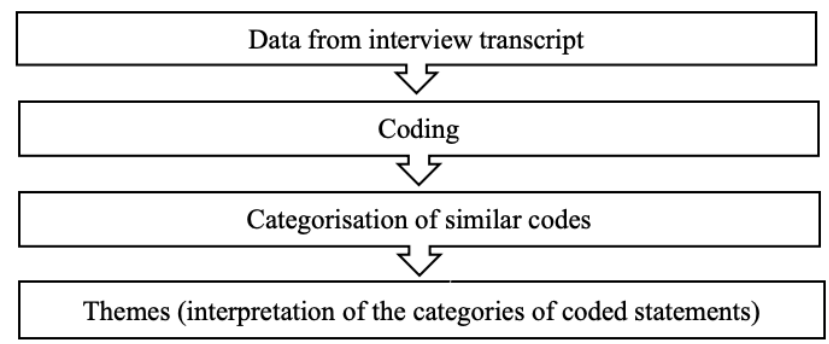

Figure 3: Steps to Derive the Themes

\section{Findings and Discussion}

As shown in Table 1, there is no significant effect of the learning material in increasing the participants' algorithm skills ( $p>.05, p=.259$ ) although the mean for post-test score $(66.9 \%)$ is slightly higher than the mean for pre-test score (64.3\%) as shown in Table 2. 
Table 1. Paired Samples Test

\begin{tabular}{|c|c|c|c|c|c|c|c|c|c|}
\hline & & & & red Differer & ces & & & & \\
\hline & & & & & $95 \% \mathrm{Co}$ & fidence & & & \\
\hline & & & & & Interv & of the & & & \\
\hline & & & Std. & Std. Error & Diffe & ence & & & Sig. (2- \\
\hline & & Mean & Deviation & Mean & Lower & Upper & $\mathrm{t}$ & $d f$ & tailed) \\
\hline Pair 1 & $\begin{array}{l}\text { PreTest - } \\
\text { PostTest }\end{array}$ & -2.64516 & 12.80247 & 2.29939 & -7.34115 & 2.05082 & -1.150 & 30 & 259 \\
\hline
\end{tabular}

Table 2. Paired Samples Statistics

\begin{tabular}{lllccc}
\hline & & & & $\begin{array}{c}\text { Std. } \\
\text { Deviation }\end{array}$ & $\begin{array}{c}\text { Std. Error } \\
\text { Mean }\end{array}$ \\
\hline Pair 1 & PreTest & 64.2903 & 31 & 19.75381 & 3.54789 \\
& PostTest & 66.9355 & 31 & 20.84696 & 3.74422 \\
\hline
\end{tabular}

This result is probably due to the frequency of the exposure to the learning materials where all the participants had only been exposed one time to these materials. Higher frequency of exposure may facilitate the participants' learning (Effiong \& Igiri, 2015) and this may potentially assist participants in producing better score for the post-test.

A total of nine participants were selected for structured interview. Table 3 shows the matrix of the selected participants' demographic background.

Table 3. Matrix of the participants' demographic background

\begin{tabular}{cccc}
\hline Participants & Age & Gender & Race \\
\hline P1 & 10 & Female & Malay \\
\hline P2 & 10 & Male & Malay \\
\hline P3 & 10 & Male & Malay \\
\hline P4 & 11 & Female & Malay \\
\hline P5 & 11 & Female & Malay \\
\hline P6 & 11 & Male & Malay \\
\hline P7 & 12 & Female & Malay \\
\hline P8 & 12 & Male & Bugis \\
\hline P9 & 12 & Male & Malay \\
\hline
\end{tabular}

Table 4 show the responses of the nine participants on their perceived learning on algorithms. The data gathered from the interview is divided into two main categories which are favourable and unfavourable responses. 
INTERNATIONAL JOURNAL OF ACADEMIC RESEARCH IN BUSINESS AND SOCIAL SCIENCES

Vol. 11, No. 14, Contemporary Business and Humanities Landscape Towards Sustainability. 2021, E-ISSN: 2222-6990 @ 2021 HRMARS

Table 4. Perceived learning of the selected participants on algorithms

\begin{tabular}{|c|c|c|c|c|c|c|c|c|}
\hline \multirow[b]{2}{*}{ Themes } & \multicolumn{4}{|c|}{ Favourable responses (\%) } & \multicolumn{4}{|c|}{ Unfavourable responses (\%) } \\
\hline & $\begin{array}{c}\text { Good } \\
\text { learning } \\
\text { quality }\end{array}$ & $\begin{array}{c}\text { Much } \\
\text { knowledg } \\
\text { e gained }\end{array}$ & Easy & Useful & $\begin{array}{c}\text { Poor } \\
\text { learning } \\
\text { quality }\end{array}$ & $\begin{array}{c}\text { Little } \\
\text { knowledg } \\
\text { e gained }\end{array}$ & Difficult & $\begin{array}{c}\text { Not } \\
\text { useful }\end{array}$ \\
\hline Participants & $8(89 \%)$ & $8(89 \%)$ & $8(89 \%)$ & $8(89 \%)$ & $1(11 \%)$ & $1(11 \%)$ & $1(11 \%)$ & $1(11 \%)$ \\
\hline
\end{tabular}

Theme 1 : Good Learning Quality

Two interview questions were related to participants' learning quality. The questions were:

Question 1(i) : $\quad$ What do think of your learning about planning of steps when doing the activity?

Question 1(ii) : $\quad$ What do think of your learning about giving step-by-step instruction when doing the activity?".

The result shows that a total of eight participants (89\%) expressed that they had good learning quality while one participant (11\%) expressed that she had poor learning quality throughout the 'planning of steps' activity (Question 1(i)).

\section{Enjoy}

Five participants (P1, P5, P6, P7, P8) commented that they enjoyed the 'planning of steps' activity mainly due to the attractive presentation of learning materials that captured their attention and aroused their learning motivation.

\section{Fun}

Three participants (P2, P3, P4) stated that the activity was fun because they were learning with their peers.

Table 5 shows the feedback from each participant on the 'planning of steps' activity. 
Table 5. Participants' responses on the 'planning of steps' activity

\begin{tabular}{|c|c|}
\hline Participant & Response \\
\hline $\mathrm{P} 1$ & $\begin{array}{l}\text { The activity looks interesting. I want to try it out when I see it. } \\
\text { Aktiviti nampak menarik. Saya hendak mencubanya bila lihat. }\end{array}$ \\
\hline P2 & $\begin{array}{l}\text { It is fun. I am happy because can do it with my friends. } \\
\text { Menyeronokkan. Saya gembira sebab boleh buat bersama dengan } \\
\text { kawan. }\end{array}$ \\
\hline P3 & $\begin{array}{l}\text { Fun and best. Because I do it in group. } \\
\text { Seronok dan best. Sebab saya buat dalam kumpulan. }\end{array}$ \\
\hline P4 & $\begin{array}{l}\text { Yes. It is fun. I learn something new. The movement, counting steps. } \\
\text { Ya. lanya menyeronokkan. Saya belajar sesuatu yang baru. Pergerakan, } \\
\text { mengira langkah. }\end{array}$ \\
\hline P5 & $\begin{array}{l}\text { I enjoy doing the activity. The pictures are nice and interesting. } \\
\text { Saya enjoy buat aktiviti itu. Gambar-gambarnya cantik dan menarik. }\end{array}$ \\
\hline P6 & $\begin{array}{l}\text { I like it. I like to draw arrows on the map (refer to the grid). } \\
\text { Saya suka. Saya suka melukis anak panah dalam peta (merujuk kepada } \\
\text { peta). }\end{array}$ \\
\hline P7 & $\begin{array}{l}\text { I do not like the activity. } \\
\text { Saya tak suka aktiviti itu. }\end{array}$ \\
\hline P8 & $\begin{array}{l}\text { Best! I enjoy doing the activity. } \\
\text { Best! Saya suka buat aktiviti itu. }\end{array}$ \\
\hline P9 & $\begin{array}{l}\text { I really like the activity. Because it is easy to do and the pictures are nice. } \\
\text { Saya sangat suka aktiviti itu. Sebab ianya senang dibuat dan gambar- } \\
\text { gambarnya cantik. }\end{array}$ \\
\hline
\end{tabular}

For question 1 (ii), eight participants (89\%) expressed that they had good learning quality throughout the 'giving step-by-step instruction' activity compared to only one participant (11\%) who expressed that she had poor learning quality.

Fun

Four participants (P2, P3, P5, P6) stated that the 'giving step-by-step instruction' activity was fun and they really liked the activity. They commented the activity was easy to be accomplished.

Learn new knowledge

Four participants (P1, P4, P8, P9) commented that they learned new knowledge while doing the activity. $\mathrm{P} 1$ and $\mathrm{P} 4$ stated that it was their first time doing such an activity.

Table 6 shows the feedback from each participant on the 'giving step-by-step instruction' activity. 
Table 6. Participants' responses on the 'giving step-by-step instruction' activity

\begin{tabular}{cl}
\hline Participant & Response \\
\hline P1 & I think it is my first time doing this activity. I gain new knowledge. \\
& Saya rasa ini pertama kali saya buat aktiviti ini. Saya dapat ilmu baru. \\
& Fun when doing the activity with friends. \\
& Seronok bila buat aktiviti dengan kawan-kawan. \\
P3 & Fun. I can write using my own sentences. \\
& Seronok. Saya boleh menulis guna ayat saya sendiri. \\
P4 & I learn steps to make fruit salad. I never make fruit salad before. \\
& Saya belajar langkah-langkah buat salad buah. Saya tak pernah buat \\
& salad buah sebelum ini. \\
P5 & I like doing the activity. It is easy. \\
& Saya suka buat aktiviti ini. Ianya mudah. \\
P6 & I like it. Because I know how to do it. \\
& Saya suka. Sebab saya tahu macam mana nak buat. \\
P7 & The activity is rather boring. I don't like it. \\
& Aktiviti agak membosankan. Saya tak suka. \\
P8 & The activity is so interesting. I am having fun doing it. \\
& Aktiviti itu sungguh menarik. Saya berasa seronok bila buatnya. \\
I understand very well how to do the activity by myself without \\
P9
\end{tabular}

Theme 2 : Much Knowledge Gained

Two interview questions were related to knowledge gained by participants in this study. The questions were:

Question 2(i) : $\quad$ When you are doing the 'planning of steps' activity, what knowledge have you gained?

Question 2(ii) : $\quad$ When you are doing the 'giving step-by-step instruction' activity, what knowledge have you gained?

Eight participants (89\%) stated that they gained much knowledge from the 'planning of steps' activity while one participant (11\%) expressed that she gained little knowledge (Question 2(i)).

Problem solving: Finding the best path

Five participants (P1, P4, P5, P8, P9) commented that they had learnt about finding the best path. From the participants' comments, it can be concluded that they managed to learn about algorithm skill as finding the best path is one of the fundamental algorithm skills (Sharma \& Khurana, 2013).

Problem solving: More than one way to solve a problem Two participants (P3, P6) stated that they had learnt that there is more than one way to solve a problem. 
Table 7 shows the feedback from each participant on the knowledge that they gained from the 'planning of steps' activity.

Table 7. Participants' responses on knowledge gained from the 'planning of steps' activity

\begin{tabular}{|c|c|}
\hline Participant & Response \\
\hline P1 & $\begin{array}{l}\text { Finding the best path to make fruit salad. } \\
\text { Mencari jalan terbaik untuk buat salad buah. }\end{array}$ \\
\hline $\mathrm{P} 2$ & $\begin{array}{l}\text { Ways to make fruit salad. } \\
\text { Cara-cara bagaimana nak buat salad buah. }\end{array}$ \\
\hline P3 & $\begin{array}{l}\text { There is more than one way to solve problem. } \\
\text { Ada lebih dari satu cara untuk selesaikan masalah. }\end{array}$ \\
\hline P4 & $\begin{array}{l}\text { Find the best path on how to make fruit salad. } \\
\text { Cari jalan terbaik untuk buat salad buah. }\end{array}$ \\
\hline P5 & $\begin{array}{l}\text { Find the best path on how to make fruit salad. } \\
\text { Cari laluan terbaik untuk buat salad buah }\end{array}$ \\
\hline P6 & $\begin{array}{l}\text { There is more than one way to solve problem. } \\
\text { Terdapat lebih daripada satu cara untuk selesaikan masalah. }\end{array}$ \\
\hline P7 & $\begin{array}{l}\text { I don't know. } \\
\text { Saya tak tahu. }\end{array}$ \\
\hline P8 & $\begin{array}{l}\text { Finding the best path to produce fruit salad. } \\
\text { Mencari laluan terbaik untuk menghasilkan salad buah. }\end{array}$ \\
\hline P9 & $\begin{array}{l}\text { Finding the best path to make fruit salad. } \\
\text { Mencari laluan terbaik untuk membuat salad buah. }\end{array}$ \\
\hline
\end{tabular}

Similar to question 2(i), eight participants stated that they gained much knowledge from the 'giving step-by-step instruction' activity compared to only one participant who expressed that she gained little knowledge although she also mentioned 'I don't know', which can be interpreted as not gaining any knowledge. Most of the participants took longer time before they could answer these two questions.

\section{Correct and accurate steps}

Seven participants (P1, P2, P3, P4, P5, P6, P8) commented that they had learned the correct and accurate steps to make fruit salad by doing the 'giving step-by-step instruction' activity.

\section{Systematic}

Participant 9 (P9) was the only participant who mentioned that he had learned about systematic way to solve a problem, which is capability needed by computational skills (Kalelioglu et al., 2016).

Table 8 shows the feedback from each participant on the knowledge that they gained from the 'giving step-by-step instruction' activity. 
INTERNATIONAL JOURNAL OF ACADEMIC RESEARCH IN BUSINESS AND SOCIAL SCIENCES

Vol. 11, No. 14, Contemporary Business and Humanities Landscape Towards Sustainability. 2021, E-ISSN: 2222-6990 @ 2021 HRMARS

Table 8. Participants' responses on knowledge gained from the 'giving step-by-step instruction' activity

\begin{tabular}{|c|c|}
\hline Participant & Response \\
\hline \multirow[t]{2}{*}{ P1 } & The correct and accurate steps to make fruit salad. \\
\hline & Langkah-langkah yang betul dan tepat untuk buat salad buah. \\
\hline \multirow[t]{2}{*}{ P2 } & $\begin{array}{l}\text { The correct and accurate steps to make fruit salad. I also learn how to } \\
\text { take care of cleanliness when making fruit salad. }\end{array}$ \\
\hline & $\begin{array}{l}\text { Langkah-langkah yang betul dan tepat untuk membuat salad buah. Saya } \\
\text { juga belajar bagaimana menjaga kebersihan apabila membuat salad } \\
\text { buah. }\end{array}$ \\
\hline \multirow[t]{2}{*}{ P3 } & The correct and accurate steps to make fruit salad. \\
\hline & Langkah-langkah yang betul dan tepat untuk membuat salad buah. \\
\hline \multirow[t]{2}{*}{ P4 } & The correct and accurate steps to make fruit salad. \\
\hline & Langkah yang betul dan tepat untuk buat salad buah. \\
\hline \multirow[t]{2}{*}{ P5 } & The correct and accurate steps to make fruit salad. \\
\hline & Langkah-langkah yang betul dan tepat untuk buat salad buah. \\
\hline \multirow[t]{2}{*}{ P6 } & The correct and accurate steps to make fruit salad. \\
\hline & Langkah-langkah yang betul dan bertepatan untuk buat salad buah. \\
\hline P7 & (The participant didn't give her answer) \\
\hline \multirow[t]{2}{*}{ P8 } & The correct and accurate steps to make fruit salad. \\
\hline & Langkah-langkah yang betul dan tepat untuk menghasilkan salad buah. \\
\hline \multirow[t]{2}{*}{ P9 } & Systematic way to make fruit salad. \\
\hline & Cara yang sistematik untuk membuat salad buah. \\
\hline
\end{tabular}

Theme 3 : Easy

Two interview questions were related to the difficulty of the activity. The questions were:

Question 3(i) : $\quad$ Do you find the' planning of steps' activity easy or difficult? Why?

Question 3(ii) : $\quad$ Do you find the 'giving step-by-step instruction' activity easy or difficult? Why?

Eight participants (P1, P2, P3, P4, P5, P6, P8, P9) mentioned that the 'planning of steps' activity was easy.

Easy to understand

Four participants (P1, P3, P4, P6) commented that the activity was easy to understand. From the comments received, it is inferred that the activity is rather simple for upper primary students. A more diverse set of algorithm learning materials with different levels of difficulties will be appropriate to facilitate further learning. According to Faber et al. (2017), students became much engaged and motivated with much difficult unplugged activities.

\section{Sufficient time}

Four participants (P2, P5, P8, P9) commented they were able to complete the activity within the given time frame.

Table 9 shows the participants' responses on the difficulty level of the 'planning of steps' activity. 
Table 9. Participants' responses on the difficulty of the 'planning of steps' activity

\begin{tabular}{|c|c|}
\hline Participant & Response \\
\hline P1 & $\begin{array}{l}\text { Easy. The material is simple and not too much. } \\
\text { Mudah. Bahannya mudah dan tidak terlalu banyak. }\end{array}$ \\
\hline P2 & $\begin{array}{l}\text { Easy. Easy to follow and did not take much time to complete it. } \\
\text { Mudah. Mudah untuk diikuti dan tak ambil masa yang lama untuk } \\
\text { siapkannya. }\end{array}$ \\
\hline P3 & $\begin{array}{l}\text { Easy. Because not many paths/ways. } \\
\text { Mudah. Sebab tak banyak laluan. }\end{array}$ \\
\hline P4 & $\begin{array}{l}\text { Easy. I can easily identify the steps through the pictures. } \\
\text { Mudah. Saya boleh kenalpasti langkah-langkah melalui gambar-gambar. }\end{array}$ \\
\hline P5 & $\begin{array}{l}\text { Easy. No need to take much time. } \\
\text { Mudah. Tak ambil masa yang lama. }\end{array}$ \\
\hline P6 & $\begin{array}{l}\text { Easy. I can easily understand the pictures and the steps. } \\
\text { Mudah. Saya mudah faham gambar-gambar dan langkah-langkah. }\end{array}$ \\
\hline P7 & $\begin{array}{l}\text { Difficult. I do not understand the material. } \\
\text { Susah. Saya tidak faham bahan itu. }\end{array}$ \\
\hline P8 & $\begin{array}{l}\text { Easy. I can complete the activity in the short time. Because it is easy to } \\
\text { understand. } \\
\text { Mudah. Saya boleh habiskan aktiviti dalam masa yang pendek. Sebab } \\
\text { ianya mudah difahami. }\end{array}$ \\
\hline P9 & $\begin{array}{l}\text { Easy. I can finish the activity within the given time. } \\
\text { Mudah. Saya boleh siapkan dalam masa yang diberikan. }\end{array}$ \\
\hline
\end{tabular}

The same eight participants (P1, P2, P3, P4, P5, P6, P8, P9) stated that the 'giving step-by-step instruction' activity was easy.

Easy to understand

Six participants (P1, P2, P3, P5, P8, P9) commented that the activity was simple to follow. Participants with age range between 10 to 12 may be given more difficult and more challenging activity.

Helpful figures

Two participants (P4, P6) commented that pictures in the learning materials were helpful. Figures such as pictures, graphs and charts are able to facilitate learning (Shabiralyani, Hasan, Hamad \& lqbal, 2015).

Table 10 shows the participants' responses on the difficulty level of the 'giving step-by-step instruction' activity. 
Table 10. Participants' responses on the difficulty of the 'giving step-by-step instruction' activity

\begin{tabular}{|c|c|}
\hline Participant & Response \\
\hline \multirow[t]{2}{*}{$\mathrm{P} 1$} & Easy. Because the steps are easy to follow. \\
\hline & Mudah. Sebab langkah-langkahnya mudah untuk diikuti. \\
\hline \multirow[t]{2}{*}{$\mathrm{P} 2$} & Easy. Each step is short and easy to understand. \\
\hline & Mudah. Setiap langkah-langkah pendek dan mudah difahami. \\
\hline \multirow[t]{2}{*}{ P3 } & Easy. No need to think much. \\
\hline & Mudah. Tak perlu fikir banyak. \\
\hline \multirow[t]{2}{*}{ P4 } & $\begin{array}{l}\text { Easy because there are pictures to help me in identifying the steps to } \\
\text { make fruit salad. }\end{array}$ \\
\hline & $\begin{array}{l}\text { Mudah sebab ada gambar-gambar yang bantu saya kenal pasti langkah- } \\
\text { langkah untuk buat salad buah. }\end{array}$ \\
\hline \multirow[t]{2}{*}{ P5 } & Easy because the steps are short and easy to understand. \\
\hline & Mudah sebab langkah-langkahnya pendek dan mudah untuk faham. \\
\hline \multirow[t]{2}{*}{ P6 } & Easy. The steps can be identified through the pictures. \\
\hline & Mudah. Langkah-langkah boleh dicam melalui gambar. \\
\hline \multirow[t]{2}{*}{ P7 } & Difficult. Because I don't understand the material. \\
\hline & Susah. Sebab saya tak faham bahan itu. \\
\hline \multirow[t]{2}{*}{ P8 } & Easy. The steps can be easily recognised. \\
\hline & Senang. Langkah-langkahnya mudah dikenali. \\
\hline \multirow[t]{2}{*}{ P9 } & Easy. Because there are not many steps to make fruit salad. \\
\hline & Mudah. Sebab tak banyak langkah untuk buat salad buah. \\
\hline
\end{tabular}

Theme 4: Useful

Two interview questions were related to the usefulness of the activity. The questions were:

Question 4(i) : Do you find the 'planning of steps' activity useful? Why?

Question 4(ii) : Do you find the 'giving step-by-step instruction' activity useful? Why?

Eight out of nine participants (89\%) felt that the 'planning of steps' activity was useful.

Applying the knowledge in daily routine

Seven participants (P1, P2, P3, P4, P5, P6, P8) stated that they could apply the knowledge gained from the 'planning of steps' activity in their daily routines including create a new menu. This indicates that the participants are capable to construct algorithms based on their prior experience (Bodner, 1987).

\section{Sequencing skill}

Participant P9 commented that he had learned sequencing skill from the 'planning of steps' activity.

Table 11 shows the participants' responses on the usefulness of the 'planning of steps' activity. 
INTERNATIONAL JOURNAL OF ACADEMIC RESEARCH IN BUSINESS AND SOCIAL SCIENCES

Vol. 11, No. 14, Contemporary Business and Humanities Landscape Towards Sustainability. 2021, E-ISSN: 2222-6990 @ 2021 HRMARS

Table 11. Participants' responses on the usefulness of the 'planning of steps' activity

\begin{tabular}{|c|c|}
\hline Participant & Response \\
\hline \multirow[t]{2}{*}{ P1 } & Useful. I can apply this knowledge in my daily routine. \\
\hline & Berguna. Saya boleh guna ilmu ini dalam kehidupan seharian saya. \\
\hline \multirow[t]{2}{*}{ P2 } & Useful. I can apply this knowledge during my scout camping. \\
\hline & $\begin{array}{l}\text { Berguna. Saya boleh guna ilmu ini masa saya pergi perkhemahan } \\
\text { pengakap. }\end{array}$ \\
\hline \multirow[t]{2}{*}{ P3 } & Useful. I can learn to make other food using this method. \\
\hline & $\begin{array}{l}\text { Berguna. Saya dapat belajar buat makanan lain menggunakan kaedah } \\
\text { ini. }\end{array}$ \\
\hline \multirow[t]{2}{*}{ P4 } & Useful. Can make other type of food using this method. \\
\hline & Berguna. Boleh buat makanan lain menggunakan kaedah ini. \\
\hline \multirow[t]{2}{*}{ P5 } & Useful. I can learn to make other type of food using this method. \\
\hline & $\begin{array}{l}\text { Berguna. Saya dapat belajar membuat makanan lain menggunakan } \\
\text { kaedah ini. }\end{array}$ \\
\hline \multirow[t]{2}{*}{ P6 } & Useful. I can learn to make other types of food using this method. \\
\hline & $\begin{array}{l}\text { Berguna. Saya dapat belajar buat makanan-makanan lain menggunakan } \\
\text { kaedah ini. }\end{array}$ \\
\hline \multirow[t]{2}{*}{ P7 } & Not useful. It is boring. \\
\hline & Tidak berguna. Membosankan. \\
\hline \multirow[t]{2}{*}{ P8 } & Useful. I can learn to make other types of food using this method. \\
\hline & $\begin{array}{l}\text { Berguna. Saya dapat belajar untuk buat makanan lain menggunakan } \\
\text { kaedah ini. }\end{array}$ \\
\hline P9 & Useful. I can use this method to make sequences on other activity. \\
\hline & $\begin{array}{l}\text { Berguna. Saya boleh guna kaedah ini untuk membuat turutan pada } \\
\text { aktiviti lain. }\end{array}$ \\
\hline
\end{tabular}

The same eight participants (89\%) felt that the 'giving step-by-step instruction' activity was useful.

Help in memorising

Seven participants (P1, P2, P3, P4, P5, P6, P9) commented that the 'giving step-by-step instruction' activity help them in memorising the steps for making fruit salad. This is diverting from the purpose of algorithm skill itself which is to guide the solving of problems. The participants might be too attracted with the making of fruit salad instead of linking it with the 'step-by-step' approach, which is an algorithm skill.

Table 12 shows the participants' responses on the usefulness of the 'giving step-by-step instruction' activity. 
Table 12. Participants' responses on the usefulness of the 'giving step-by-step instruction' activity

\begin{tabular}{|c|c|}
\hline Participant & Response \\
\hline \multirow[t]{2}{*}{ P1 } & Useful. I can memorize steps to make fruit salad easily. \\
\hline & $\begin{array}{l}\text { Berguna. Saya boleh mengingati langkah-langkah untuk buat salad buah } \\
\text { dengan mudah. }\end{array}$ \\
\hline \multirow[t]{2}{*}{$\mathrm{P} 2$} & Useful. Can remember how to make fruit salad. \\
\hline & Berguna. Boleh ingat macam mana nak buat salad buah. \\
\hline \multirow[t]{2}{*}{ P3 } & Useful. I can remember how to make fruit salad. \\
\hline & Berguna. Saya boleh ingat bagaimana nak buat salad buah. \\
\hline \multirow[t]{2}{*}{ P4 } & $\begin{array}{l}\text { Useful. Easier to memorise steps to make fruit salad and other types of } \\
\text { food. }\end{array}$ \\
\hline & $\begin{array}{l}\text { Berguna. Lebih mudah untuk hafal langkah-langkah buat salad buah dan } \\
\text { makanan lain. }\end{array}$ \\
\hline \multirow[t]{2}{*}{ P5 } & Useful. Help me to remember better. \\
\hline & Berguna. Membantu saya untuk ingat dengan lebih baik. \\
\hline \multirow[t]{2}{*}{ P6 } & Useful. I can remember well. \\
\hline & Berguna. Saya boleh ingat dengan baik. \\
\hline \multirow[t]{2}{*}{ P7 } & Not useful. It is boring. \\
\hline & Tidak berguna. Membosankan. \\
\hline \multirow[t]{3}{*}{ P8 } & Useful. \\
\hline & Berguna \\
\hline & (The participant didn't give his reason) \\
\hline \multirow[t]{2}{*}{ P9 } & Useful. It helps me in memorising steps for making fruit salad. \\
\hline & $\begin{array}{l}\text { Berguna. la membantu saya mengingati langkah-langkah buat salad } \\
\text { buah. }\end{array}$ \\
\hline
\end{tabular}

\section{Unfavourable Response}

Participant 7 (P7) gave unfavourable responses during the interview session. To the researchers' opinion, there is possibility that she felt unmotivated because she was unable to do well with the learning materials and this led to her unfavourable responses for all interview questions. P7 was one of the two students who showed deterioration in algorithm learning as her post-test score was lower than her pre-test score.

\section{Conclusion}

This study shows that UPA is an appropriate alternative approach to teach CT skills especially for schools located in areas with limited access to adequate technological infrastructure. From the responses gathered through interviews, four main themes (Good Learning Quality, Much Knowledge, Easy and Useful) had emerged and these positive themes provide evidence on the appropriateness of employing UPA for teaching the algorithm aspect of CT. Although there is an insignificant difference between the pre-test and post-test that measures the learning of the algorithms skill, the average post-test scores are higher than the pre-test scores. Besides adding to the literature on the method of teaching CT skills (Kong \& Abelson, 2019), the Ministry of Education, State Education Department, District Education Office, schools and teachers may use this study as a reference in establishing a comprehensive UPA module for teaching algorithms aspect of CT skills. Such module 
can be a good reference for teachers across the nation. The findings will add Future studies may consider reinforce the learning of the algorithms aspect by allowing students to experience with more learning materials and replicate the study in suburban and urban schools to examine the generalisability of the findings.

\section{Acknowledgements}

The research is supported by Universiti Malaysia Sarawak.

\section{References}

Abas, A. (2016). Computational thinking skills to be introduced in school curriculum next year. News Straits Times. Retrieved from https://www.nst.com.my/news/2016/08/164732/ computational-thinking-skills-be-introduced-school-curriculum-next-year

Amrita, U. N., Muir, A., \& Rao, B. (2016). Of Elephants and Nested Loops: How to Introduce Computing to Youth in Rural India. ACM Press, 137-146.

Anna, F., \& Sabariah, S. (2014). Robotics in Education: An Overview. International Journal on ELearning Practices (IJELP), 1(2), 119-129.

Anna, F., Sabariah, S., Wong, W., \& Muralindran, M. (2017). Computational Thinking and Tinkering: Exploration Study of Primary School Students' in Robotic and Graphical Programming. International Journal of Assessment and Evaluation in Education, 7(1993), 44-54.

Aubrey, S. (2019). Sarawak needs assistance to equip schools with ICT. Borneo Post Online. Retrieved from https://www.theborneopost.com/2019/11/14/sarawak-needs-assistance-toequip-schools-with-ict/

Belanger, C., Christenson, H., \& Lopac, K. (2018). Confidence and Common Challenges: The Effects of Teaching Computational Thinking to Students Ages 10-16 (Master's thesis). St. Catherine University, St. Paul, Minnesota.

Bocconi, S., Chioccariello, A., Dettori, G., Ferrari, A., \& Engelhardt, K. (2016). Developing computational thinking in compulsory education - Implications for policy and practice. doi:10.2791/792158.

Brackmann, C. P., Román-González, M., Robles, G., Moreno-León, J., Casali, A., \& Barone, D. (2017). Development of Computational Thinking Skills through Unplugged Activities in Primary School. Proceedings of the 12th Workshop on Primary and Secondary Computing Education WiPSCE' $17,65-72$.

Bodner, G. M. (1987). The Role of Algorithms in Teaching Problem Solving. Journal of Chemical Education, 64, 513-514.

Chen, C. J., \& Keong, M. W. Y. (2017). Affording inclusive dyslexia-friendly online text reading. Universal Access in the Information Society, 16(4), 951-965.

Computer Science Without a Computer. (n.d.). Retrieved from https://csunplugged.org/en/

Effiong, O. E., \& Igiri, C. E. (2015). Impact of Instructional Materials in Teaching and Learning of Biology in Senior Secondary Schools in Yakurr Lg A. International Letters of Social and Humanistic Sciences, 62, 27-33.

Erickson, J. (2019). Algorithms. Retrieved from http://jeffe.cs.illinois.edu/teaching/algorithms/

Faber, H. H., Wierdsma, M. D. M., Doornbos, R. P., Ven, J. S. V. D., \& Vette, K. D. (2017). Teaching Computational Thinking to Primary School Students via Unplugged Programming Lessons. Journal of the European Teacher Education Network, 12, 13-24. 
Gardeli, A., \& Vosinakis, S. (2017). Creating the computer player: an engaging and collaborative approach to introduce computational thinking by combining 'unplugged' activities with visual programming. Italian Journal of Educational Technology, 25(2), 36-50.

Kale, U., Akcaoglu, M., Cullen, T., Goh, D., Devine, L., Calvert, N., \& Grise, K. (2018). Computational what? Relating computational thinking to teaching. TechTrends, 62(6), 574-584.

Kalelioglu, F., Gülbahar, Y., \& Kukul, V. (2016). A Framework for Computational Thinking Based on a Systematic Research Review. Baltic Journal of Modern Computing 4, 3, 583-596.

Keong, M. W. Y. (2017). Framework of Friendly Online Game (PhD's thesis). Universiti Malaysia Sarawak, Kota Samarahan, Malaysia.

Kong, S. C., \& Abelson, H. (2019). Computational thinking education. Singapore, Singapore: Springer Nature.

Mironova, O., Amitan, I., \& Vilipõld, J. (2012). Computational Thinking and Flexible Learning: Experience of Tallinn University of Technology. Lecture Notes in Information, 23/24, 183-188.

Musiani, F. (2013). Governance by Algorithms. Journal on Internet Regulation, 2(3),1-8.

National Research Council. (2012). Education for Life and Work: Developing Transferable Knowledge and Skills in the 21st Century.

Repenning, A., Webb, D., \& loannidou, A. (2010). Scalable game design and the development of a checklist for getting computational thinking into public schools. Proceedings of the 41st ACM Technical Symposium on Computer Science Education - SIGCSE '10, 265.

Sadatul, M. R. (2017). Penggunaan ICT masih hadapi kekangan - Mahdzir. Utusan Melayu. Retrieved from https://www.utusan.com.my/

Samuel, R. J., \& Zaitun, A. B. (2007). Do teachers have adequate ICT resources and the right ICT skills in integrating ICT tools in the teaching and learning of English Language in Malaysian schools? The electronic journal on information systems in developing Countries (EJISDC), 29(2), 1-15.

Selby, C. C. (2013). Computational Thinking: The Developing Definition. Paper presented at the Conference on Innovation and Technology in Computer Science Education, Aberdeen, United Kingdom.

Sharma, P., \& Khurana, N. (2013). Study of Optimal Path Finding Techniques. International Journal of Advancements in Technology, 4(2), 124-130.

Shute, V. J., Sun, C., \& Asbell-Clarke, J. (2017). Demystifying computational thinking. Educational Research Review, 22(October), 142-158.

Shabiralyani, G., Hasan, K. S., Hamad, N., \& Iqbal, N. (2015). Impact of Visual Aids in Enhancing the Learning Process Case Research: District Dera Ghazi Khan. Journal of Education and Practice, 6(19), 226-233.

UNESCO Institute for Statistics. (2014). ICT in Education in Asia: A comparative analysis of ICT integration and e-readiness in schools across Asia. Report presented to the UNESCO. Retrieved from http://uis.unesco.org/sites/default/files/documents/information-communicationtechnologies-education-asia-ict-integration-e-readiness-schools-2014-en_0.pdf

Weintrop, D., Orton, K., Horn, M., Beheshti, E., Trouille, L., Jona, K., \& Wilensky, U. (2014). Computational Thinking in the Science Classroom: Preliminary Findings from a Blended Curriculum, 5. Retrieved from https://ccl.northwestern.edu/papers/2014/ Weintrop_et_alNARST_2015.pdf

Wing, J. (2006). Computational thinking. ACM Communications, 49(3), 33-35. 
Wing, J. M. (2008). Computational thinking and thinking about computing. Philosophical Transactions of the Royal Society A: Mathematical, Physical and Engineering Sciences, 366(1881), 37173725.

Wright, G., Rich, P. J., \& Leatham, K. (2012). How programming fits with technology education curriculum. Technology and Engineering Teacher, 71 (3), 3-9.

Zaman, H. B., Ahmad, A., Nordin, A., Yamat@Ahmad, H., Aliza, A., Ang, M. C., ... Salwana, M. S. E. (2019). Computational Thinking (CT) Problem Solving Orientation Based on LogicDecomposition-Abstraction (LDA) by Rural Elementary School Children Using Visual-Based Presentations. In E. Yohannes, T. K. Shih, \& C. Y. Lin (Eds.), Advances in Visual Informatics. . Proceedings of the $6^{\text {th }}$ International Visual Informatics Conference (pp. 713-728). Bangi, Malaysia 